\title{
Dual Portraits of the Deceased in Yangqiaopan M1, Jingbian, Shaanxi
}

\author{
Leslie WALLACE*
}

\begin{abstract}
Murals decorating an Eastern Han tomb excavated in Jingbian, Shaanxi include two large-scale representations of the deceased who appears in a processional scene on the left front wall of the tomb wearing typical Han elite dress, and then again on the rear wall in a regional version of a spirit seat (lingwei) composition, clean-shaven and donning a hairstyle uncommon in Han mortuary art. This paper considers these depictions in terms of Han pictorial conventions and argues that they are dual portraits of the deceased in which different attributes of his political, social, and cultural identity are stressed.
\end{abstract}

Keywords: Han tomb murals, Han northern frontier, portraiture, processional scene, spirit seat (lingwei)

\section{Dvojni portret umrlega v grobnici Yangqiaopan M1 v mestu Jingbian v pro- vinci Shaanxi}

\section{Izvleček}

Stenske poslikave v grobnici iz dinastije Vzhodni Han, ki so jo izkopali v mestu Jingbian v provinci Shaanxi, vključujejo dve večji upodobitvi pokojnika. Prva se pojavi v procesiji na levi strani prednjega zidu in prikazuje pokojnika, oblečenega $v$ tipična hanska oblačila višjega sloja, druga pa je vidna na zadnji steni, kjer je pokojnik prikazan v lokalni varianti t. i. sedeža duše (lingwei). Tu je upodobljen s sveže obrito brado in nenavadno pričesko, kar se razlikuje od ostalih pričesk v hanski grobni umetnosti. Pričujoči prispevek proučuje te upodobitve $\mathrm{v}$ okviru običajnega slikovnega gradiva dinastije Han in trdi, da poslikavi prikazujeta dvojni portret pokojnega $\mathrm{z}$ namenom prikazovanja različnih lastnosti njegove politične, družbene in kulturne identitete.

Ključne besede: poslikave $\mathrm{v}$ grobnicah iz dinastije Han, severna meja v dinastiji Han, portreti, prizori sprevodov, sedež duše

Leslie WALLACE, Assistant Professor, 
Since their discovery in the 1970s, the second century CE murals decorating a tomb in Helinge'er 和林格爾, Inner Mongolia have often been referenced in studies of Han visual and material culture. ${ }^{1}$ Through a series of processional scenes and depictions of cities where the deceased held office, the murals highlight the career of a high ranking Han official stationed along the northern frontier with one scene depicting the local population of the city of Ningcheng lined up neatly in rows, a mass of typecast "barbarians" (Fig. 1).

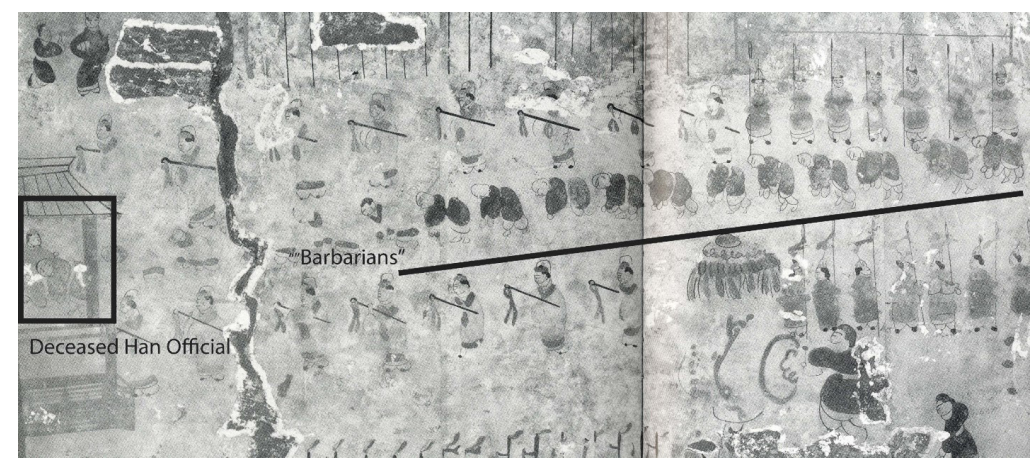

Figure 1: Detail of the city of Ningcheng with "barbarians" submitting to the deceased, Helingeer, Inner Mongolia (After Nei Menggu wenwu kaogu yanjiusuo 2007, 134-35).

Other murals in first and second century $\mathrm{CE}$ tombs discovered in the past decades across northern Shaanxi and south central Inner Mongolia complicate this simplistic rendering of life along the Han northern frontier. Although the preservation of murals in each tomb varies and no inscriptions remain allowing us to identify the official rank and status of the tomb occupants, the size of these tombs suggests the burials of low-level elites. Each tomb has a unique pictorial program largely composed of scenes common in the interior of the Han Empire, but sometimes with significant combinations and modifications. ${ }^{2}$

This paper will focus on two representations of the deceased in one of these tombs-Yangqiaopan 楊橋畔 M1, a back to back double-chambered, barrel

1 Helinge'er is a large brick tomb with three main chambers running front to back from east to west. Two smaller chambers are attached to the north and south sides of the front chamber and another smaller chamber is attached to the south side of the middle chamber. The tomb is decorated throughout by paintings that run from the floor to the apex of the ceiling and the imagery in the front and middle chambers focuses on the career of the deceased. For an overview of the tomb and its imagery see Berger (1980, 220-32), Bulling (1977/78, 79-103), and Nei Menggu wenwu kaogu yanjiusuo (2007). For a detailed study of the iconography of this tomb see James (1980).

2 For a general introduction to these tombs see Huang $(2008,104-19)$. 
vaulted tomb constructed of grey bricks excavated in Jingbian 靖邊, Shaanxi in 2005 (Fig. 2). ${ }^{3}$
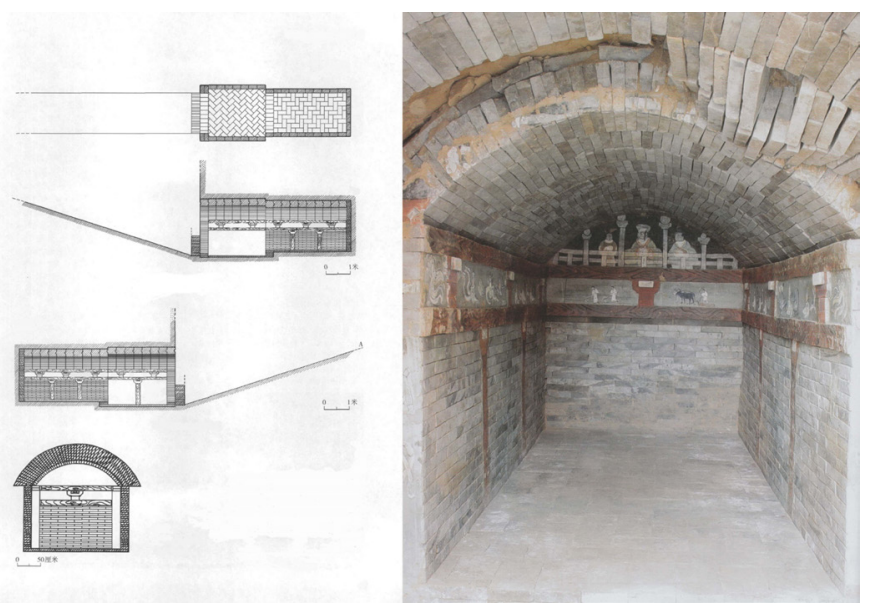

Figure 2: Diagram and photograph of the rear room of Yangqiaopan M1, Jingbian, Shaanxi (After Shaanxi sheng kaogu yanjiuyuan et al. 2009, figs. 2-5; Shaanxi sheng kaogu yanjiuyuan 2009, 82).

Tomb murals decorate the right, left, and rear walls of both chambers as well as a narrow portion of the wall facing the tomb doorway created by the difference in size in the front and rear chambers. Timber architecture is simulated throughout by painted wooden pillars, brackets, and timber beams. One distinctive element of the pictorial program of this tomb is that it features two large-scale representations of the deceased-one on the left wall of the front chamber and one on the rear wall of the rear chamber, but in each composition the man is depicted with different facial features, hairstyles, and forms of headdress. ${ }^{4}$ After an overview of the conventions of representing individuals in Han mortuary art and related methodological problems, I will focus on each of these depictions in turn, and then consider them as a dual portrait of the deceased in which different attributes of his political, social, and cultural identity are stressed.

3 For an overview of the tomb, a diagram, and photographs see Shaanxi sheng kaogu yanjiuyuan (2009, 80-113) and Shaanxi sheng kaogu yanjiuyuan et al. (2009).

4 Although Han tombs decorated with murals and reliefs often contain multiple representations of the deceased, who is either depicted outright or whose presence is suggested by other elements in the composition, Yangqiaopan M1's pictorial program is only one of two tombs excavated so far that contains this combination of two large-scale representations of the deceased. The other tomb that has similar paired representations of the deceased is Haotan 郝灘 M1, Dingbian 定邊, Shaanxi, whose pictorial program is also discussed in what follows. 


\section{Han Portraits}

In early China, representations of the deceased first appear on silk banners associated with a posthumous ascent/journey during the late third and second centuries $\mathrm{BCE}$, the most famous of which is the silk funerary banner recovered from Mawangdui 馬 王堆 Tomb 1 (ca. $168 \mathrm{BCE}$ ). By the first and second centuries CE, the deceased is represented in tombs and aboveground mortuary shrines doing everyday things, like enjoying a banquet or managing their estate. Regardless of the composition, format, and medium, these depictions often lack the elements of individualisation commonly associated with portraiture today ${ }^{5}$ and instead were standardised, with information pertinent to the person's identity communicated (much as it would have been in life), through details of dress, gesture, pose, interaction with other figures, and the position of scenes within larger compositions. Often with the aid of inscriptions, generic exemplary types were converted into representations of individuals, which highlighted a person's rank and social status, providing emulative models for the viewer and solidifying the social order and the individual's place within it. ${ }^{6}$ As is the case of the representations of the deceased in Yangqiaopan M1, details in dress and hairstyle often communicated the most important and defining aspects of identity.

Based on their intentional lack of mimesis or individualisation, the generic character of depictions of the deceased in Han tombs have led some scholars to reject outright the idea that they are "true portraits." For example, regarding a "portrait in a true sense,"Max Loehr writes, "What counts is the convincing, lifelike expression, the expression of the human face rather than that attained through gesture, pose or action" (Loehr 1960, 214). ${ }^{7}$ In a more recent survey of the development of Chinese portraiture, Dorothy C.Y. Ching is more noncommittal, stressing that portraiture evolved from, "physical approximations to more detailed likenesses," and that, "while the genre of portraiture emerges before Han times (third century BCE), it is not always clear if surviving works would have been identified as belonging to that genre" (Ching 2016, 139). Such comments suggest the intellectual baggage that comes with this term and its association in traditional art historical scholarship with Renaissance ideas of the role of mimesis and humanistic individualism. ${ }^{8}$ As we shall

5 For a review of these associations and general definitions, see West (2004, 21-41).

6 See Spiro (1991, 14-21) and Vinograd (1992, 20-21). For other studies focused on or touching upon Han portraiture see Bush and Shih (2012); Ching (2016); Lancman (1966); Loehr (1960); Murray (2007, 27-36); Seckel (1993); Shan (1987), Nagahiro (1965 and 1984); and Zheng (2000).

7 For similar views see Seckel (1993) and Shan (1987).

8 Wu Hung $(2009,21)$ does not reject the classification of Han representations of the deceased as portraits, but does stress two drawbacks of integrating Han posthumous portraits into the larger genre: 1) in general studies of portraiture, posthumous portraits lose their original ritual setting and visual logic, and 2) when representations of the deceased are studied as portraits, scholars run the risk of overlooking other ways in which the deceased may be represented in the tomb. 
see, the dual representations of the deceased in Yangqiaopan M1 further challenge traditional ideas of portraiture by not only representing the deceased as idealised, but based on the pictorial conventions noted above as two "different" people, or rather, as I will argue, two different social versions of the same man.

\section{The Processional Scene}

Standing in the doorway of the tomb, the deceased first appears on the left wall of the front room in Yangqiaopan M1, riding in a zhaoche 軺車, a type of carriage with an umbrella-shaped canopy with dangling tassels reserved for high officials (Lim 1987, 116) (Fig. 3).

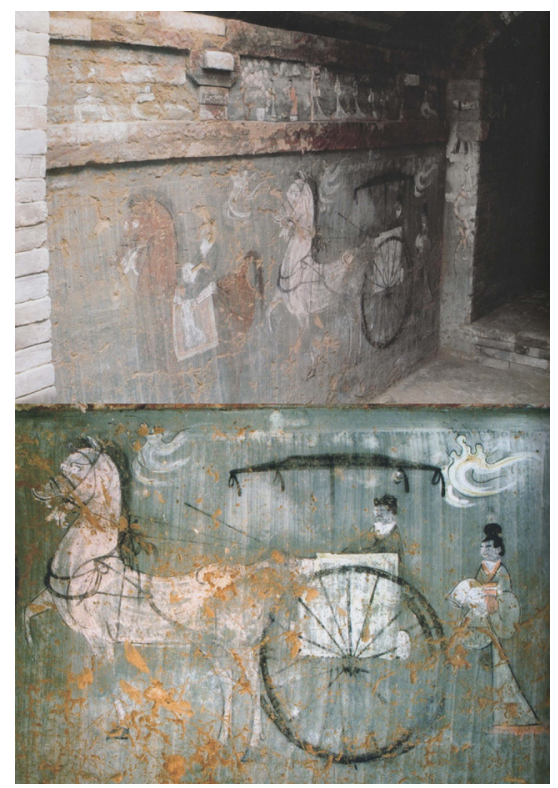

Figure 3: Two images of the processional scene depicted on the left wall of the front chamber of Yangqiaopan M1, Jingbian, Shaanxi (After Shaanxi sheng kaogu yanjiuyuan 2009, 96 and 102).

He wears a black rectangular hat and sports a thin moustache. A rider precedes him wearing a green tunic and white baggy pants. The details of the rider's face are no longer clear, but he wears a high headdress with two extensions that frame his face. Behind the carriage a woman walks who is probably a female servant, holding an embroidered bag draped over her arms. Above the large mural are several smaller scenes. The one closest to the doorway is too damaged to reconstruct, but 
the other three depict two figural scenes, and a man riding in a cloud chariot. ${ }^{9}$ All of the figures on the left wall, including the members of the processional scene, face outward toward the door of the tomb.

Processional scenes are common in Eastern Han tombs decorated with murals and carved stone reliefs, where the deceased may or may not appear as part of a larger procession of chariots and mounted riders. ${ }^{10}$ They can be divided into three general types. The first depicts quotidian imagery of a chariot or groups of chariots and riders that represent the rank and status of the deceased and/or may depict important events in his life. One of the most famous examples of this type of procession scene are the murals mentioned at the beginning of this paper in the tomb at Helinge'er, in which the deceased's official career and rise in rank are indicated by inscriptions as well as ever larger groups of horses and riders. This imagery is based on a complex system of carriages where the shape of the carriage and the scale of the procession were determined by rank. Typically the person who held the highest rank rode in the middle of the procession (Lim 1987,116-17; Powers 1992, 323; and Wu 1998, 22). ${ }^{11}$ Many variations on this theme exist-from the dynamic processional scenes that appear in the murals decorating the tomb at Helinge'er to the more static representations that appear on tombs and shrines decorated with carved reliefs in Shandong, such as the those that appear in the Wu Family Shrines. ${ }^{12}$

9 The archaeological report identifies the first group of figures as illustrating the story of the wife of Qiu $\mathrm{Hu}$ 秋胡, a moral exemplar whose story appears in the Lienü zhuan 列女傳 (Biographies of Exemplary Women, ca. $18 \mathrm{BCE}$ ) and is also depicted in other examples of Han mortuary art. See Shaanxi sheng kaogu yanjiuyuan et al. $(2009,41)$ and for an overview of other representations of the story of the wife of Qiu Hu see Wu (1987, 77-78). The story of Confucius, Laozi, and the child prodigy, Xiang Tuo 項夢, another figural grouping depicted in Han murals and stone reliefs also appears on the right wall of the tomb. See Shaanxi sheng kaogu yanjiu yuan $(2009,82)$. For other depictions of Confucius, Laozi, and Xiang Tuo, see Nylan (2005). The inclusion of such "Confucian"/historically-themed subject matter is not common in Han tomb murals or reliefs in northern Shaanxi and south central Inner Mongolia, and potentially adds another layer to the political, social, and cultural affiliations depicted in these reliefs.

10 For a list of tombs decorated with murals that depict quotidian (vs. immortal) procession scenes (車馬出行 chema chuxing) see Yi (2010). As Yi (ibid., 13) notes, the chariot processions in the tombs excavated at Yangqiaopan and Haotan are representative of murals excavated in Shaanxi and south central Inner Mongolia, however they are the only two tombs to date in which the processional occupies such a large space in the overall pictorial program.

11 For a detailed study of carriages as markers of emblems and status see Hayashi (1966). For a similar chariot scene carved on stone reliefs in Sichuan see Yu (1987).

12 These combine homage and processional scenes in the format of a central pavilion with archer and horse beneath a tree and a chariot procession. The identification of the central figure in the pavilion scene and the overall interpretations of this scene are contested. For a review of the interpretations of the central homage scene and its various elements see $\mathrm{Wu}(1989,196-213)$ and Thompson (2005). 
Two other major types of processional scenes are found in Eastern Han tombs. Some tombs and stone sarcophagi are decorated with processions that at first glance seem similar to the first type outlined above, but can be differentiated from the rank and status processional scenes by the distinctive shape of the carriage included, which would have been used to transport the deceased to the tomb (Wu 1998). ${ }^{13}$ More common are scenes that depict afterlife journeys with figures riding on or in chariots pulled by real or fantastic animals. An example of this type of procession appears in the murals decorating the right wall of the front chamber of Yangqiaopan M1, where an entourage of cloud chariots pulled by tigers, snakes, and other creatures glide across the tomb wall.

The chariot preceded by a horseback rider and followed by the women on foot depicted on the left wall of the front room of Yangqiaopan M1 clearly falls into the first type of processional scene that represents the rank and status of the deceased. Although lacking the dynamic nature of the processional scenes in the murals at Helinge'er or the exacting cartouches identifying the rank of members of chariot processions in the carvings that decorate the Wu Family Shrines, the composition and function of the processional scene in Yangqiaopan M1 is distilled into its most basic components, and amplified via its size respective to the tomb's overall pictorial program. This amplification may have been a regional development, as another Han tomb excavated nearby in 2003 in Haotan 郝灘, Dingbian 定邊, Shaanxi, contains a similar large-scale composition. The tomb in Haotan is a double-chambered brick tomb composed of one large chamber and a small side chamber, with murals decorating only the large chamber (Shaanxi sheng kaogu yanjiu suo et al. 2004; Shanxi sheng kaogu yanjiuyuan 2009, 47-79) (Fig. 4).

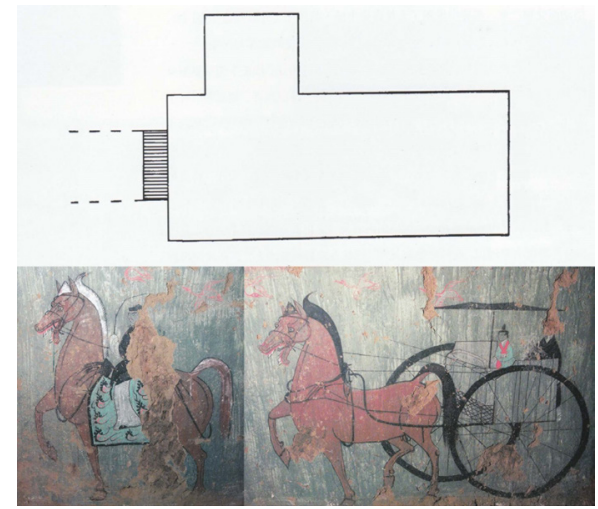

Figure 4: Diagram of Haotan M1 and processional scene depicted on the left wall of the tomb, Dingbian, Shaanxi (After Shaanxi sheng kaogu yanjiuyuan 2009, 66-67).

13 For a rubbing of this stone see Gao (2000, fig. 55). 
In this tomb the deceased also appears in an official carriage and is accompanied by his wife; the pair are preceded by a rider. As in the case of the murals in Yangqiaopan M1, the processional scene in Haotan M1 also occupies a larger portion of the overall pictorial program and takes up the entire left wall of the tomb between the entrance to the small side chamber and the rear wall. ${ }^{14}$

\section{The Spirit Seat}

The second large-scale representation of the deceased in Yangqiaopan M1 appears on the top of rear wall of the rear chamber where the deceased is depicted between his wife and another figure on the left (Fig. 5).

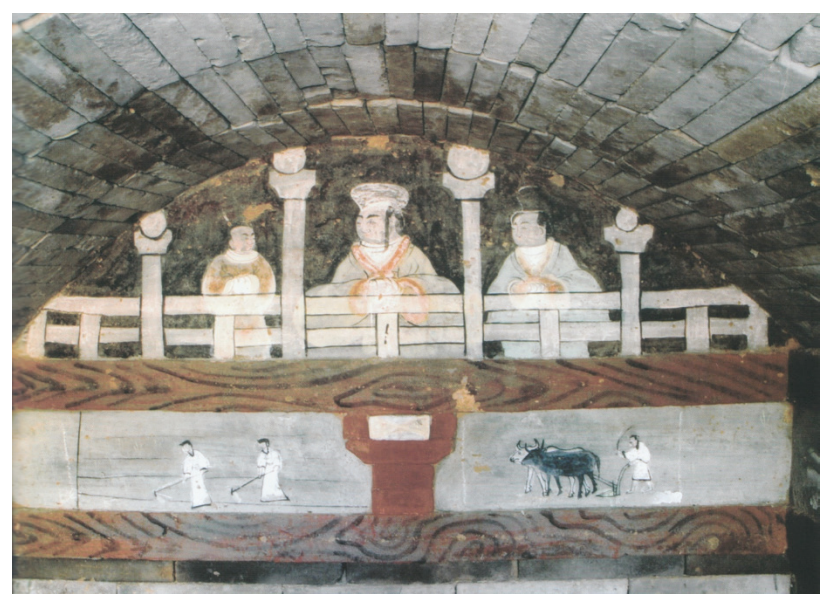

Figure 5: Detail of the portrait of the deceased on the rear wall of Yangqiaopan M1, Jingbian, Shaanxi (After Shaanxi sheng kaogu yanjiuyuan 2009, 111).

All three figures are painted in three-quarter view and have their hands in their sleeves drawn to their chests in a gesture of respect (gongshou 拱手). The deceased and his wife wear white tunics drawn across their chests with orange trim. The wife's hair is drawn high atop her head and the man's hair may be styled in the same fashion, but this area of the mural is damaged. The man has long tendrils that hang down on either side of his clean-shaven face. The attendant on the left

14 A second Eastern Han tomb painted with murals excavated in Yangqiaopan in 2015 also includes a similar simplified and amplified variation of the chariot procession scene on the northern wall of its front room, but does not include a large-scale portrait of the deceased on its rear wall. See Shaanxi sheng kaogu yanjiuyuan et al. (2017). 
is dressed in a tunic that is not drawn across the chest, and wears a black hat or has his hair piled on top of his head decorated with a feather. All three figures stand behind a balustrade. The deceased and his wife look toward the left wall and the attendant glances toward the couple. Below these three figures are two agricultural scenes.

This depiction of the deceased on the rear wall of Yangqiaopan M1 is a variation of a type of posthumous portrait that gained popularity in the late Eastern Han and developed out of earlier displays of mortuary goods representing the spirit seat (lingwe $i$ 靈位) of the deceased that enabled him/her to see, eat, and smell in their afterlife existence (Wu 2009 and 2010, 68-84). ${ }^{15}$ Based on Han mortuary rituals, early spirit seats were three-dimensional representations where the space in front of a screen or beneath a canopy was left empty, as is the case of the empty couch in the northern chamber of Mawangdui Tomb 1. In some first and second century $\mathrm{CE}$ tombs the spirit seat continued to be left blank, but in others the deceased is represented figuratively, such as in the tomb excavated at Anping 安 平, Hebei $(176 \mathrm{CE})$, where a portrait of the deceased with a retinue of officials appears in the room to the right of the main chamber. ${ }^{16}$

Another look at the murals decorating the rear wall of the main chamber in Haotan M1 suggests that the depiction of the deceased on the rear wall of Yangqiaopan M1 may be a regional variation on the spirit seat composition. In the tomb in Haotan, and in the same position on the rear wall, the deceased and his wife are depicted in three-quarter view turned slightly toward one another, also with their hands inside their sleeves drawn to their chests (Fig. 6).

15 This type of posthumous portrait continued to be popular in periods after the Han dynasty (see Hong 2014).

16 Unlike the representation of the deceased in Yangqiaopan M1, most first and second century CE figurative and non-figurative spirit seats appear to the side of the front chamber of the tomb away from the rear chamber where the coffin was placed. An example of a second century tomb with a non-figurative spirit seat is Dahuting 打虎亭 M1, Zhengzhou 鄭州, Henan, which included a low table beneath a tent on a stone platform at the right end of the main chamber (Wu 2009 and 2010, 68-84). For more on Dahuting M1 see Henan sheng wenwu yanjiusuo and An Jianhuai (1993) and Pirazzoli-t'Serstevens (2010). For the Anping tomb see Hebei sheng wenwu yanjiusuo (1990) and Hsu (2004). In terms of layout and iconography, the composition and placement of the deceased's portrait in the rear wall of the rear chamber in Yangqiaopan M1 shares more similarities with much later sixth century posthumous portraits where the deceased is depicted on the northern wall of single-chambered tombs with elongated passageways. In these tombs the deceased-a male, female, or a couple - is depicted frontally facing the doorway to the tomb, beneath a canopy enjoying food and drink served by servants as can be seen in the tomb of Xu Xianxiu 徐顯秀 (d. $571 \mathrm{CE}$ ), excavated in Taiyuan 太原, Shanxi. Interestingly, the individualisation seen in these later portraits (in this particular example, Xu Xianxiu wears a fur coat) may also be anticipated in the representation of the deceased in Yangqiaopan M1. See Wu (2009, 30-33). For more on Xu Xianxiu's tomb see Taiyuan shi wenwu kaogu yanjiusuo (2005) and Lingley (2014). 


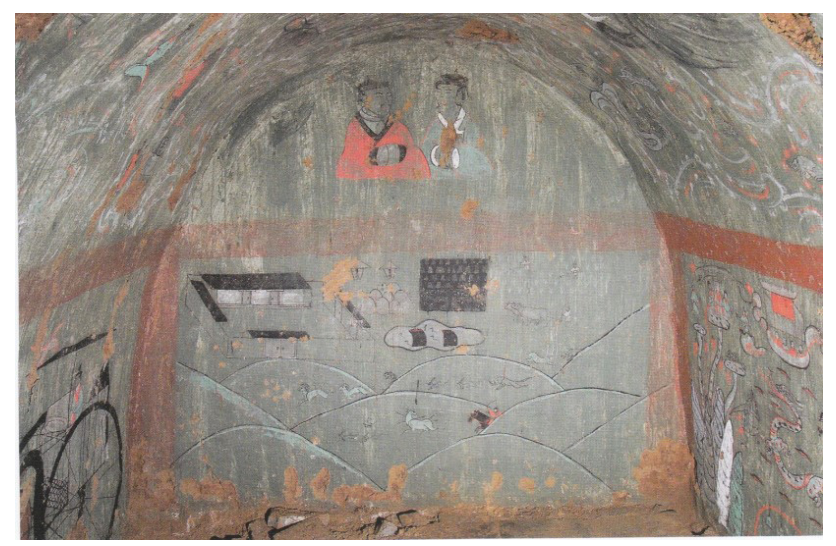

Figure 6: Detail of the portrait of the deceased on the rear wall of Haotan M1, Dingbian, Shaanxi (After Shanxi sheng kaogu yanjiuyuan 2010, fig. 5).

Below them is a walled compound and agricultural and hunting scenes. The similar compositions of the rear wall of Yangqiaopan M1 and Haotan M1 suggests a modified form of other Han spirit seat representations, with the agricultural and hunting scenes in Haotan M1 and agricultural scenes in Yangqiaopan M1, suggesting ancestral sacrifices offered in perpetuity, and the agricultural estate the deceased might enjoy in the afterlife.

\section{Dual Portraits}

The shared aspects of the pictorial program of Yangqiaopan M1 and Haotan M1, tombs which both contain similar large-scale representations of the deceased on the rear and left walls, suggest these images were dual representations of the deceased expressing different aspects of their social status and identity. A comparison of these representations of the deceased in both tombs also highlights the ways in which the depiction of the deceased on the rear wall of Yangqiaopan M1 differs from other first- and second-century CE representations of Han elite males.

If we first look at the depictions of the deceased riding a chariot on the left walls of both tombs, the imagery is strikingly similar (Figs. 3 and 4). Sadly, the part of the mural depicting the man's face has been damaged in Haotan M1, but overall it is most likely that, like his compatriot in Yangqiaopan M1, he was depicted, as most Han elite males were, wearing a squared off black hat with a thin moustache. This is indeed how the deceased appears on the rear wall of Haotan M1, beside his wife above their afterlife estate (Fig. 6). In Haotan M1, the agricultural estate 
below the couple on the rear wall, and the status-defining processional scene so common in other tombs, clearly expresses their actual or desired status as part of the Han elite using visual imagery common in Han mortuary art.

Similar desires form the backbone of the dual portraits of the deceased in Yangqiaopan M1, but the differences in the details of costume, dress, and hairstyle suggests a more complicated set of social identities and alliances. In the front room the deceased first appears in the processional scene wearing the same hat and dress as the man depicted in Haotan M1, which, as previously stated, commonly appears in Han visual representations of elite males across media (Fig. 3). But his companions in this scene are a curious bunch. Is the female behind him his wife? A servant? What exactly is she carrying? Perhaps more significantly, the rider who leads the procession wears a tall hat that leans slightly to the front and has extensions framing his face, a headdress not represented in other Han tomb murals, stone reliefs, or figurines.

When we return to the representation of the deceased on the rear wall, differences with the portrayal of Han elite males in other tombs is even more drastic (Fig. 5). First and foremost, here the deceased is clean-shaven and has long tendrils hanging down on either side of his face standing in stark contrast to the standard black scholar's cap and thin moustaches donned by Han elite males in many tombs. The dress and hairstyle/headdress of the man on the left in this image is also suspect. The man does not wear the standard Han tunic that is drawn across the chest and is secured by a belt, and the feather in his hat/hairstyle is also uncommon in other first- and second-century CE tombs (Wallace 2019). Combined with the unique hat of the rider in the procession in the front room, this mix of unfamiliar clothing and hairstyles in general suggests the multicultural world of the Han northern frontier, and may be related to the Han practice of incorporating foreign groups into their armies. ${ }^{17}$ More importantly, the more exotic representation of the deceased on the rear wall of the tomb, combined with the familiar representation of the deceased on the left wall in the front room, shows a skilful manipulation of details in dress and hairstyles that may have appealed to different social and/or cultural groups living in the region.

\section{Conclusion}

Whether or not the murals depicted in Yangqiaopan M1 reflect what life was like on the ground for the deceased, they do show the conscious choice by the patrons

17 For the practice of employing foreign soldiers in Han armies and/or the Han policy of "Using Foreigners to Control Foreigners (Yi Yi zhi Yi 以夷制夷)” see Hong (1958), Shangguan Xuzhi (2006), and Xing (1973). 
of this tomb-whether it be the deceased or the deceased's family - to choose imagery very different from that of the deceased official buried in the Eastern Han tomb at Helinge'er. ${ }^{18}$ Rather than a figure on a high dais separated from the local population, with rows of bowing "barbarians" (see Fig. 1)—non-Han hairstyles and dress, and by extension foreign groups and/or customs, are incorporated into the murals in Yangqiaopan M1 in a way that is uncommon in other Han tombs where foreigners are typically portrayed with stereotypical features and/or in scenes of combat and submission. ${ }^{19}$ Instead in Yangqiaopan M1 we find figures wearing foreign dress and hairstyles depicted both in the procession scene on the left wall of the front chamber, and also joining the deceased in the spirit seat portrait on the rear wall. The representation of the deceased on the rear wall takes this a step further and here the deceased himself dons a foreign hairstyle.

It is tempting to analyse these murals in terms of a Hu-Han dichotomy, identifying the deceased as being Xiongnu 匈奴 or some other group described in historical texts, as has been done in the case of another Han tomb in the region, Fenghuangshan 鳳凰山 M1, which also incorporates figures wearing non-Han hairstyles and dress (Ma 2003 and Zhang 2000). ${ }^{20}$ But I would suggest it is more useful to think of the two representations of the deceased in Yangqiaopan M1 as a skilful handling of multiple social, cultural, and political identities and as an appeal to different groups along the Han northern frontier. Although we may not be able to establish a one-to-one correlation between the hairstyle and dress of these figures and groups mentioned in Han texts (a methodology which is in itself dubious at best), the dual representations of the deceased in Yangqiaopan M1 are striking in the way in which the man is depicted spanning both worlds, or rather occupying the space in-between. Imagery of figures wearing different hairstyles and dress, seen by those taking part in funerary rituals, could be just as socially and/or politically charged as the scenes of filial piety or historical exemplars chosen in other areas. ${ }^{21}$ In this tomb, as in other tombs in the region, this visual strategy may have been used to appeal to or engender a sense of solidarity among competing groups navigating the borderlands of the Han northern frontier.

18 Although these murals were intended first and foremost to create a microcosm for the deceased, the denizens in the afterlife were not their only intended viewers, and those participating in the funeral would have also seen the decoration of the tombs. As Miranda Brown (2007) has shown, Eastern Han funerals were important venues for public display, providing the opportunity for mourners and attendees to strengthen existing social networks and relationships.

19 For studies on the depiction of foreigners in Han mortuary art, see Xing (2000 and 2005), Zheng (1998), and Zhu (2017).

20 For an alternate interpretation of this imagery that rejects this binary analysis, see Wallace (2019).

21 For examples of scholars that have analysed the political and social implications of the imagery decorating Han tombs and mortuary shrines, see Powers (1992) and Wu (1989). 


\section{References}

Berger, Patricia Ann. 1980. "Rites and Festivities in the Art of Eastern Han China." PhD Diss., University of California.

Brown, Miranda. 2007. The Politics of Mourning in Early China. Albany: State University of New York Press.

Bulling, Anneliese Gutkind. 1993. "The Eastern Han Tomb at Ho-Lin-Ko-êrh (Holingol)." Archives of Asian Art 31: 79-103.

Bush, Susan, and Hsio-yen Shih. 2012. Early Chinese Texts on Painting, 2nd edition. Hong Kong: Hong Kong Baptist University Press.

Ching, Dorothy C. Y. 2016. "The Language of Portraiture in China." In A Companion to Chinese Art, edited by Martin J. Powers and Katherine R. Tsiang, 136-57. Malden, MA and Oxford: Wiley Blackwell.

Gao, Wen 高文. 2000. Zhongguo huaxiangshi quanji 7: Sichuan Han huaxiangshi 中國畫像石全集 7: 四川漢畫像石 (Complete Collection of Chinese Pictorial Carved Stones 7: Han Pictorial Stones from Sichuan). Zhengzhou: Henan meishu chubanshe.

Hayashi, Minao 林巳奈夫. 1966. “Gokan jidai no shaba gyōretsu 後漢時代の車 馬行列 (Han Dynasty Horse and Chariot Processions).” Tōhō Gakuhō 東方 學報 37 (March): 183-226.

Hebei sheng wenwu yanjiusuo 河北省文物研究所. 1990. Anping Dong Han bibuamu 安平東漢壁畫墓 (The Eastern Han Tomb with Murals from Anping). Beijing: Wenwu chubanshe.

Henan sheng wenwu yanjiusuo 河南省文物研究所 and An Jianhuai 安金槐. 1993. Mixian Dabuting Han mu 密縣打虎亭漢墓 (The Han Tomb from Dabuting, Mixian). Beijing: Wenwu chubanshe.

Huang, Peixian 黄佩賢. 2008. Handai mushi bibua yanjiu 漢代墓室壁畫研究 (Research on Han Dynasty Tomb Murals). Beijing: Wenwu chubanshe.

Hong, Jeehee. 2014. "Changing Roles of the Tomb Portrait: Burial Practices and Ancestral Worship of the Non-Literati Elite in North China (1000-1400).” Journal of Song-Yuan Studies 44: 203-64.

Hong, Tingyan 洪廷彦. 1953. “Liang Han Sanguo de 'Yi Bing'两漢三國的“夷 兵' (Foreign Soldiers of the Han and Three Kingdoms Period)." Wen shi zhi 文史哲 3: 29-35.

Hsu, Xin-Mei Agnes. 2004. "Pictorial Eulogies in Three Eastern Han Tombs at Wangdu and Anping." PhD Diss., University of Pennsylvania.

James, Jean M. 1980. "An Iconographic Study of Two Late Han Funerary Monuments: The Offering Shrines of the Wu Family and the Multichamber Tomb at Holingor." PhD Diss., University of Iowa.

Lancman, Eli. 1966. Chinese Portraiture. Rutland, VT: C.C Tuttle and Company. 
Lim, Lucy. 1987. “Transportation: Horses and Carriages.” In Stories from China's Past: Han Dynasty Pictorial Tomb Reliefs and Archaeological Objects from Sichuan Province, People's Republic of China, edited by Lucy Lim, 114-17. San Francisco: Chinese Culture Foundation of San Francisco.

Lingley, Kate A. 2014. "Silk Road Dress in a Chinese Tomb: Xu Xianxiu and Sixth Century Cosmopolitanism.” Silk Road 12: 1-12.

Loehr, Max. 1960. “The Beginnings of Portrait Painting in China." Proceedings of the International Congress of Orientalists, Twenty-Fifth Congress 5: 210-14. Ma, Liqing 馬利清. 2003. “Nei Menggu Fenghuangshan Han mu bihua er ti 内 蒙古鳳凰山墓壁畫二題 (Two Questions about Murals in a Han Tomb from Fenghuangshan, Inner Mongolia).” Kaogu yu wenwu 考古與文物 2: 60-69. Murray, Julia K. 2007. Mirror of Mortality: Chinese Narrative Illustration and Confucian Ideology. Honolulu: University of Hawai'i Press.

Nagahiro, Toshio 長広敏雄. 1965. “Portraiture and Figure Painting in Han Art." In Kandaigazō no kenkyū 漢代畫象の研究 (Research on Han Dynasty Representational Art). Tokyo: Chūō Kōron Bijutsu Shuppan.

—, ed.1984. “Kandai shōsōga no seishinshi teki haikei 漢代肖像画の精神史的 背景 (Background on the History of Thought about Han Dynasty Portraiture).”In Chügoku bijutsu ronshū 中国美術論集, 183-97. Tōkyō: Kōdansha.

Nei Menggu wenwu kaogu yanjiusuo 內蒙古文物考古研究所. 2007. Helingge'er Han mu bihua 和林格爾畫墓壁畫 (Han Tomb Murals from Helinge'er). Beijing: Wenwu chubanshe.

Nylan, Michael. 2005. “Confucius Meeting Laozi' Pictorial Stone.” In Recarving China's Past: Art, Archaeology, and Architecture of the Wu Family Shrines, edited by Naomi Noble Richard, 261-63. New Haven and London: Yale University Press. Powers, Martin J. 1992. Art and Political Expression in Early China. New Haven: Yale University Press.

Seckel, Dietrich. 1993. "The Rise of Portraiture in Chinese Art." Artibus Asiae 53 $(1,2): 7-26$.

Shaanxi sheng kaogu yanjiusuo 陕西省考古研究所 and Yulin shi wenwu guanli weiyuanhui 榆林市文物管理委員會. 2004. “Shaanxi Dingbian xian Haotan faxian Dong Han bihua mu 陕西定邊縣郝滩發現東漢壁畫墓 (An Eastern Han Tomb with Murals Excavated at Dingbian, Shaanxi)." Wenwu 文物 5: 20-21.

Shaanxi sheng kaogu yanjiuyuan 陝西省考古研究院. 2010. Han Tang muzang bibua baohu yu xiufu 漢唐墓葬壁画保護與修復 (The Conservation and Restoration of Han and Tang Tomb Murals). Xi'an: San Qin chubanshe.

一. 2009. Bishang danqing: Shaanxi chutu bihua ji 壁上丹青: 陝西出土壁畫 集 (Ancient Pigments on Walls: A Collection of Tomb Murals Excavated from Shaanxi), Vol. 1. Beijing: Kexue chubanshe. 
Shaanxi sheng kaogu yanjiuyuan 陝西省考古研究院, Yulin shi wenwu yanjiusuo 偷林市文物研究所, and Jingbian xian wenwu guanli bangongshi 靖邊縣文 物管理辦公室. 2009. “Shaanxi Jingbian Dong Han bihuamu 陝西靖邊東 漢壁畫墓 (An Eastern Han Tomb with Murals from Jingbian, Shaanxi).” Wenwu 文物 2: 32-42.

Shaanxi sheng kaogu yanjiuyuan 陝西省考古研究院 and Jingbian xian wenwu guanliban 靖邊縣文物管理辦. 2017. “Shaanxi Jingbian xian Yangqiaopan, Qushuhao Dong Han bihuamu fajue jianbao 陝西靖邊縣楊橋畔渠樹壕東 漢壁畫墓發現簡報 (A Preliminary Report on the Excavation of an Eastern Han Tomb with Murals at Qushuhao, Yangqiaopan, Jingbian, Shaanxi).” Kaogu yu wenwu 考古與文物 1:3-26.

Shan, Guoqiang 單國䮠. 1987. "Xiaoxiang huaxing zhi chutan 肖像畫性質初探 (A Preliminary Study of Portrait Painting)." In International Symposium on Art Historical Studies 6: Portraiture, edited by Kokusai Kōryū Bijtsushi Kenkyūkai et.al, 1-12. Kyoto: Kyoto University.

Shangguan, Xuzhi 上官緒智. 2006. “Liang Han zhengzhi 'yi yi zhi yi’ celüe yunyong de zhuyao fangshi he tedian 两漢政權“以夷制夷”策略運用的主要 方式和特點 (The Main Methods and Characteristics of the Han Regime's Strategy of 'Using Foreigners to Fight Foreigners').” Nandu xuetan 南都學 壇 6:1-6.

Spiro, Audrey G. 1991. Contemplating the Ancients: Aesthetic and Social Issues in Early Chinese Portraiture. Berkeley: University of California Press.

Taiyuan shi wenwu kaogu yanjiusuo 太原市文物考古研究所. 2005. Bei Qi Xu Xianxiu mu 北齊徐顯秀墓 (The Northern Qi Tomb of Xu Xianxiu). Beijing: Wenwu chubanshe.

Thompson, Lydia. 2005. "Central Pavilion or Homage Scene Pictorial Stone with Chariot Procession, Archer and Horse beneath a Tree." In Recarving China's Past: Art, Archaeology, and Architecture of the Wu Family Shrines, edited by Naomi Noble Richard, 265-69. New Haven and London: Yale University Press.

Vinograd, Richard. 1992. Boundaries of the Self: Chinese Portraits, 1600-1900. Cambridge: Cambridge University Press.

Wallace, Leslie V. 2019. "Does a Feather in Your Hat a Barbarian Make? Headgear and Hairstyles in Han Dynasty Tomb Murals in the Ordos." In The Art and Archaeology of Bodily Adornment: Studies from Central and East Asian Mortuary Contexts, edited by Sheri Lullo and Leslie V. Wallace, 155-69. London: Routledge.

West, Shearer. 2004. Portraiture. Oxford and New York: Oxford University Press. Wu, Hung. 1987. "Myths and Legends in Han Funerary Art: Their Pictorial Structure and Symbolic Meanings as Reflected in Carvings on Sichuan 
Sarcaphogi." In Stories from China's Past: Han Dynasty Pictorial Tomb Reliefs and Archaeological Objects from Sichuan Province, People's Republic of China, edited by Lucy Lim, 72-81. San Francisco: Chinese Culture Foundation of San Francisco.

- 1989. The Wu Liang Shrine: The Ideology of Early Chinese Pictorial Art. Stanford: Stanford University Press.

—. 1998. "Where Are They Going? Where Did They Come From? - Hearse and 'Soul-Carriage' in Han Dynasty Tomb Art." Orientations 29 (6): 22-31.

—. 2009. "Enlivening the Soul in Chinese Tombs." RES: Anthropology and Aesthetics 55/56: Absconding (Spring-Autumn): 21-41.

-. 2010. Art of the Yellow Spring: Understanding Chinese Tombs. Honolulu: University of Hawai'i Press.

Xing, Yitian 邢義田. 1973. “Dong Han de hubing 東漢的胡兵 (Foreign Soldiers during the Eastern Han).” Zhengzhi daxue xuebao 政治大學學报 12: 143-66.

—. 2000. "Gudai Zhongguo ji Ou Ya wenxian tuxiang yu kaogu ziliao zhong de 'huren’ waimao 古代中國及歐亞文獻, 圖像與考古資料中的“胡人’外貌 (The Appearance of 'Barbarians' as Seen in Ancient Chinese and Non-Chinese Literary, Pictorial, and Archaeological Sources)." Meishu shi yanjiu jikan 美術史研究集刊 9: 15-99.

—. 2005. "Handai huaxiang Hu Han zhanzheng tu de goucheng, leixing yu yiyi 漢代画像胡漢戰爭圖的構成類型與意義 (The Composition, Types, and Meaning of Han Dynasty Images of Hu-Han Battle Scenes).” Meishu shi yanjiu jikan 美術史研究集刊 19: 63-132.

Yi, Sa 伊薩. 2010. “Beifang Handai bihua chema chuxing tu chushi 北方漢代 壁畫墓車馬出行图初識 (Horse and Chariot Processions in Han Dynasty Tomb Murals from the Northern Frontier).” Wu Han Wenbo 武漢文博 1: $10-14$.

Yu, Dezhang. 1987. “Yangzishan Tomb Number One: A Vaulted Brick Tomb.” In Stories from China's Past: Han Dynasty Pictorial Tomb Reliefs and Archaeological Objects from Sichuan Province, People's Republic of China, edited by Lucy Lim, translated by Wu Hung, 182-93. San Francisco: Chinese Culture Foundation of San Francisco.

Zhang, Haibin 張海斌. 2000. "Shilun Zhongguo jingnei Dong Han shiqi Xionngu muzang ji xiangguan wenti 試論中國境内東漢時期匈奴墓葬 及相關問題 (A Discussion about Eastern Han Xiongnu Tombs Inside China and Related Questions).” Nei Mengu wenwu kaogu 内蒙古文物考 古 1: 14-22.

Zhao, Huacheng 趙化成. 1989. “Hanhua suojian Handai che ming kaobian 漢 畫所見漢代車名考讋 (Distinguishing the Names of Han Dynasty Chariots seen in Han Pictures).” Wenwu 文物 3: 76-82. 
Zheng, Yan. 1998. "Barbarian Images in Han Period Art." Orientations 29 (6), (June): 50-59.

—. 2000. “Muzhu huaxiang yanjiu 墓主畫像研究 (Research on Images of the Deceased).” In Liu Dunyuan xiansheng jinian wenji 劉敦願先生紀念文集, edited by Shandong daxue kaogu xuexi 山東大學考古學係, 450-86. Jinan: Shandong daxue chubanshe.

Zhu, Hu 朱汻. 2017. Han huaxiang Huren tuxiang yanjiu 漢畫像胡人圖像研究 (Research on Images of Foreigners in Han Pictures). Beijing: Shenghuo dushu xinzhi sanlian shudian. 